Jurnal Konstruksi Hukum | ISSN: 2746-5055

Vol. 2, No. 1, Januari 2021 Hal. 149-153 | Tersedia online di https://www.ejournal.warmadewa.ac.id/index.php/jukonhum DOI: https://10.22225/jkh.2.1.2985.149-153

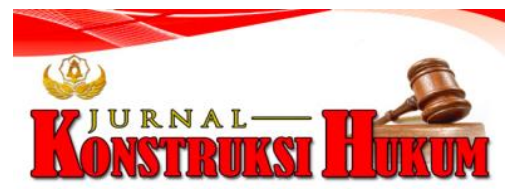

\title{
SANKSI PIDANA TERHADAP SISWA YANG MELAKUKAN TINDAK PIDANA PENGANIAYAAN KEPADA GURU
}

\author{
Komang Devi Triveni, A.A.Sg. Laksmi dewi luh, Putu Suryani \\ Fakultas Hukum Universitas Warmadewa, Denpasar-Bali, Indonesia
}

\begin{abstract}
Abstrak
Pendidikan adalah hal pokok yang akan menopang kemajuan suatu bangsa. Guru merupakan tenaga profesional yang mempunyai tugas mengajar mendidik dan melatih. Tugas guru yaitu mengajar siswa agar memiliki pengetahuan dan keterampilan masing-masing bidang pelajaran. Dalam menjalankan kewajibannya Guru dilindungi oleh Pasal 39 Ayat (1) Undang-Undang Nomor 14 Tahun 2005 tentang Guru dan Dosen dan diperkuat dengan terbitnya Peraturan Pemerintah Nomor 74 Tahun 2008. Dalam pelaksanaannya Guru sering kali mendapatkan perlakuan tidak menyenangkan seperti penganiayaan yang dilakukan oleh siswanya hingga menyebabkan kematian terhadap guru dan sanksi pidana yang dapat dijatuhi kepada siswa tersebut merujuk pada Pasal 338 tentang Pembunuhan dimana penganiayaan dengan sengaja menghilangkan nyawa orang lain. Penelitian ini bertujuan untuk menjelaskan pengaturan tindak pidana penganiayaan yang dilakukan siswa kepada guru dan menjelaskan sanksi pidana bagi siswa yang melakukan tindakan penganiayaan kepada guru. Penelitian ini menggunakan metode hukum normatif dan analisis interpretasi hukum serta pemaparan, karena ini berkaitan dengan atuaran sanksi pidana maka pendekatan yang digunakan adalah pendekatan perundangundangan. Sumber data yang digunakan adalah data hukum prime dan sekunder. Hasil penelitian menunjukkan bahwa Dalam Kitab Undang-Undang Hukum Pidana Bab XX tentang penganiayaan, hal ini berguana untuk memberi efek jera terhadap siswa itu sendiri. Kitab Undang-Undang Hukum Pidana sanksi pidana terhadap pelaku merujuk pada Pasal 338 Kitab Undang-Undang Hukum Pidana tentang pembunuhan mengingat pelaku masih dibawah umur maka hukuman yang diberikan kepada pelaku paling lama (satu perdua) dari maksimum hukuman pidana penjara bagi orang dewasa sebagaimana telah diatur dalam Undang-Undang Nomor 11 Tahun 2012 mengenai Sistem Peradilan Anak.
\end{abstract}

Kata Kunci: Sanksi Pidana; Siswa; Penganiayaan Guru

\begin{abstract}
The education is the main thing that will sustain the progress of a nation. Teachers are professionals who have the task of teaching, educating and training. The teacher's job is to teach students to have the knowledge and skills of each subject area. In carrying out their obligations, teachers are protected by Article 39 Paragraph (1) of Law Number 14 of 2005 concerning Teachers and Lecturers and strengthened by the issuance of Government Regulation Number 74 of 2008. In practice, Teachers often receive unpleasant treatment such as persecution by students until causing the death of the teacher and the criminal sanction that can be imposed on the student refers to Article 338 concerning Murder where persecution deliberately takes the life of another person. This study aims to explain the management of criminal acts of molestation committed by students to teachers and to explain the criminal sanctions for students who commit acts of molestation to the teacher. This research uses normative legal methods and analysis of legal interpretation and exposure, because this is related to the outcome of criminal sanctions, the approach used is the statutory approach. The data sources used were prime and secondary legal data. The results showed that in the Criminal Code Chapter XX concerning persecution, this is useful to provide a deterrent effect on the students themselves. The Criminal Code for criminal sanctions against the perpetrator refers to Article 338 of the Criminal Code regarding murder, considering that the perpetrator is still a minor, the maximum sentence given to the perpetrator (one half) of the maximum imprisonment for adults as regulated in Law Number 11 of 2012 concerning the Juvenile Justice System.
\end{abstract}

Keywords: Criminal Sanctions; Students; Teacher's persecution

\section{PENDAHULUAN}

Pendidikan adalah hak yang bisa didapat oleh semua orang dan pendidikan menjadikan seseorang lebih berguna tidak hanya untuk diri sendiri tetapi untuk masyarakat dan juga negara. ada pendidikan yang bermutu disuatu negara maka negara tersebut akan lebih maju dari negara yang tidak memiliki sistem pendidikan yang bermutu, dengan ada pendidikan maka akan berpengaruh kepada sumber 
daya manusianya. Dengan melaksanakan kewajiban pemerintah agar masyarakat mendapatkan pendidikan yang sebagaimana mestinya.

Pendidikan yang baik akan menghasilkan seorang yang baik pula. Undang-Undang Nomor 20 Tahun 2003 mengenai Sistem Pendidikan Nasional pendidikan yaitu menciptakan dukungan sepenuhnya dengan melaksanakan kegiatan belajar dan mengajar berdasarkan potensi yang dimiliki masing-masing peserta didik, agar mempunyai kemampuan dan bermanfaat bagi masyarakat dan Negara (Neolaka, 2017). Belajar tidak hanya dilaksanakan dilingkungan sekolah tetapi dirumah dan di lingkungan masyarakat sekitarnya tidak ada pendidikan maka bisa dikatakan bahwa suatu Negara akan jauh tertinggal dari Negara yang memiliki kualitas pendidikan yang maju.

Fungsi sekolah itu sendiri sebagai badan edukatif yang tidak dapat dipisahkan kedudukannya sebagai lembaga formal untuk membentuk insan yang memiliki kedewasaan jasmani dan rohani. Pendidikan nasional yang juga secara nomina fungsinya telah tertuang dalam Undang-Undang Sistem Pendidikan Nasional Nomor 20 Tahun 2003. Namun sebagai lembaga edukatif pemahaman fungsi pendidikan harus tetap juga merujuk pada berbagai pandangan para pakar sebagai sarana dalam mengoptimalkan fungsinya. Beberapa pakar yang dirumuskan berkaitan dengan fungsi sekolah yaitu :

1. Bogardus yaitu menolong anak untuk mengerti huruf, serta dapat menjalankan kegiatan yang luas mengenai ada kesenjangan adat dan kebiasaan.

2. Vembrito yaitu transmisi kebudayaan media membudayakan masyarakat melalui peserta didik dan untuk menjamin ada pembauran sosial

Guru merupakan seorang pengajar yang berkewajiban membentuk kepribadian peserta didik, serta memiliki wawasan yang cukup luas mengenai profesi yang dijalankannya. Selain itu juga harus memiliki kualifikasi formal dan keahlian khusus untuk membangun sistem pengajaran yang berkualitas. Mengenai dunia pendidikan guru mempunyai tiga peran pokok yaitu :

1. Peran profesional adalah ada kaitannya dengan keahliannya sebagai pengajar dan mengasuh serta memberikan bekal ilmu kepada para siswanya

2. Peran manusiawi adalah untuk menjadikan guru agar dapat menjalankan perannya sebagai pengajar dan menjadikan siswanya berguna dan membentuk pribadi yang bisa diterima oleh masyarakat.

3. Peran kemasyarakatan yaitu sebagai bagian dari Negara dan masyarakat, peran guru adalah mampu menciptakan interaksi sosial yang baik agar menjadikan tumpuan serta tujuan masyarakat dimasa yang akan datang (Taufik, 2013).

Dalam dunia pendidikan tidak luput dari kekerasan bahkan penganiayaan. Penganiayaan yaitu berniat dengan berencana agar memicu rasa perih atau cedera yang akibatnya merupakan kehendak pelaku (Sudibyo \& Kiyamudin, 2019a). Penganiayaan yang terjadi antara guru dan siswa sering kali kita ketahui guru yang melakukan penganiayaan terhadap siswanya, namun dengan perkembangan teknologi yang semakin maju kita sering mendengar jika siswa yang melakukan penganiayaan terhadap gurunya bahkan disaat jam pembelajaran dan pengajaran berlangsung. Jadi tidak hanya orang dewasa saja yang melakukan penganiayaan tersebut bahkan anak di bawah umur pun melakukan hal yang sama seperti orang dewasa perbuat. Jika kita melihat dari dampak perkembangan dan kemajuan pembangunan yang cepat jelas ada hal negatif dan positifnya. Ada perubahan gaya hidup dan perubahan sosial berakibat terhadap nilai dan perilaku siswa (Mohammad Taufik , 2014). Hal ini bertujuan untuk memberikan perlindungan hukum bagi guru dalam melaksanakan tugas keprofesionalannya dari segala anomali atau tindakan semena-mena dari yang mungkin atau berpotensi menimpanya dari pihak-pihak yang tidak bertanggung jawab. Untuk itu, sudah saatnya jika guru membangun kekuatan solidaritas untuk mendorong pemerintah memperbaiki kondisi kerja guru dan melindungi profesi mereka dengan kekuatan hukum yang jelas (Sudibyo \& Kiyamudin, 2019b). Penelitian ini bertujuan menjelaskan pengaturan tindak pidana penganiayaan yang dilakukan oleh siswa kepada guru dan mengetahui sanksi pidana bagi siswa yang melakukan tindak penganiayaan kepada guru

\section{METODE PENELITIAN}

Tipe penelitian yang digunakan adalah tipe penelitian Hukum Normatif karena pengkajiannya dilakukan dengan studi kepustakaan seperti perundang-undangan teori hukum yang berkaitan dengan masalah yang diteliti. Sesuai dengan tipe penelitian dengan menggunakan Normatif maka 
pendekatan dalam penelitian ini menggunakan pendekatan perundang-undangan dan pendekatan konseptual (Waluyo, 2002). Adapun sumber bahan hukum yang digunakan yakni bersumber dari penelitian kepustakaan yaitu berupa Bahan hukum primer yaitu bahan-bahan hukum yang mengikat berupa undang-undang yakni Undang-Undang Dasar Negara Republik Indonesia Tahun 1945 Kitab Undang-Undang Hukum Pidan Undang-Undang Nomor 12 Tahun 1954 tentang Dasar Pendidikan dan pengajaran di sekolah Undang-Undang Nomor 14 Tahun 2005 mengenai Guru dan Dosen Undang-Undang Nomor 11 Tahun 2012 mengenai Sistem Peradilan Anak. Teknik pengumpulan data dengan menggunakan teknik pencatatan membaca buku-buku peraturan perundang-undangan serta daftar bacaan lainnya yang berkaitan dengan permasalahan yang penulis bahas. Semua bahan-bahan yang sudah didapat selanjutnya disusun dan dianalisis secara sistematis dengan menggunakan argumentasi hukum berdasarkan logika hukum deduktif dan hasilnya disajikan secara deskriptif analisis.

\section{HASIL DA N PEMBAHASAN}

\section{Pengaturan Tindak Pidana Penganiayaan yang Dilakukan Siswa Kepada Guru}

Guru adalah pendidik profesional yang memiliki kualifikasi akademik dan kompetensi mewujudkan tujuan pendidikan nasional dan mengajarkan suatu ilmu pengetahuan dalam bidang tertentu dengan kewajiban utama membimbing memelihara menempa mengarahkan menjaga dan menuntut peserta didik pada jalur pendidikan formal (Kunandar, 2011). Siswa merupakan anak didik yang memiliki tujuan untuk menjadi manusia yang mempunyai ilmu pengetahuan dan mampu bersaing di dunia pendidikan serta membentuk pribadi yang mandiri. Pentingnya peran Guru tidak terlepas dari perlindungan hukum yang diberikan untuk Guru yang diatur dalam Undang-Undang Nomor 14 Tahun 2005 mengenai Guru dan Dosen dan terbitnya Peraturan Pemerintah Nomor 74 Tahun 200.

Pengertian tindak pidana yaitu merupakan terjemahan dari Strafbaar Feit perilaku yang berpantangan dengan hukuman yang berlaku, dan mengenai risiko berbentuk pidana disesuaikan dengan kesalahan yang dilanggar dan kesalahan tersebut akan dikenakan sanksi. Kitab UndangUndang Hukum Pidana tidak memperoleh definisi mengenai apa penjelasan dari Starfbaar Feit itu sendiri. Tindak pidana dikatakan seimbang dengan delik yang berasal dari bahasa latin yakni kata Delictum. Secara umum tindak pidana terhadap tubuh pada Kitab Undang-Undang Hukum Pidana disebut dengan Penganiayaan yang diatur dalam Bab XX Kitab Undang- Undang Hukum Pidana mengenai penganiayaan.

Penganiayaan adalah dengan sengaja menyebabkan perasaan tidak enak rasa perih atau cedera atau berniat merusak kesehatan orang. Dalam melaksanakan kewajibannya sebagai pengajar guru sering kali mendapatkan perilaku yang tidak menyenangkan seperti penganiayaan disaat jam pembelajaran dan pengajaran yang dilakukan oleh siswanya. Tidak sedikit guru yang mengalami kekerasan di dalam dunia pendidikan seperti yang kita ketahui bahwa seorang guru yang seharusnya dihormati malah sebaliknya siswa tersebut melakukan tindak pidana penganiayaan terhadap gurunya. Dengan ada pengaturan tindak pidana penganiayaan terhadap guru ini untuk mengetahui bahwa guru dalam melaksanakan kewajiban dan kedudukannya dilindungi oleh Undang-Undang Nomor 14 Tahun 2005 mengenai Guru dan Dosen.

Proses pendidikan akan berhasil jika dalam manajemen pendidikan sekolah mempunyai sistem mekanisme yang mampu mengatur dan mengoptimalkan sebagai komponen dan sumber daya pendidikan yang ada. Menurut Muhaimin, (2009) Interaksi guru dan peserta didik tidak hanya berjalan denga baik dengan tujuan pengaturan terhadap siswa yang melakukan tindak pidana penganiayaan kepada guru untuk memberikan efek jera dan menyesal terhadap siswa tersebut serta tidak ada kekerasan di dalam dunia pendidik lagi. Serta dengan ada tujuan pengaturan tersebut untuk melindungi siswa yang menjadi salah satu bagian dari pembangunan nasional dan menunjang kemajuan Negara, dan membangun disiplin terhadap siswa serta mengubah tingkah laku siswa tersebut agar menjadi sesuai dengan yang diharapkan serta tidak ada siswa lain lagi yang melakukan perbuatan tersebut. Dan diharapkan siswa tersebut mampu memperbaiki pribadi berdasarkan perlakuan dan pendidikan yang diberikan selama menjalani hukuman.

Tujuan pengaturan tersebut untuk menegaskan bahwa seorang guru juga mendapatkan perlindungan hukum dalam menjalankan tugasnya yang dimana sudah diatur dalam UndangUndang Nomor 14 Tahun 2005 mengenai Guru dan Dosen. Anak yang melakukan tindak pidana serta berhadapan dengan hukum akan dilindungi sesuai dengan Undang-Undang Nomor 35 Tahun 
2014 tentang perlindungan anak. Untuk itu peran dari sekolah Komisi Perlindungan Anak Indonesia dan masyarakat juga sangat dibutuhkan yang nantinya untuk kejiwaan siswa tersebut apakah nantinya bisa diterima kembali oleh masyarakat dan tidak ada penentangan dan penolakan. Serta tidak ada diskriminasi dan menjamin apakah siswa tersebut tidak mengulangi perbuatannya dilain waktu.

\section{Sanksi Pidana Maka Pendekatan yang terhadap Siswa yang Melakukan Penganiayaan}

Mengenai pembelajaran dan pengajaran memiliki hubungan yang kuat. Dimana siswa yang menempuh pendidikan tidak akan lepas dari kebiasaan belajar dan mengenai pengajaran itu sendiri dilakukan oleh seorang yang telah mempunyai keahlian khusus mengenai pengajaran serta menyampaika informasi atau pengetahuan kepada siswa. Proses penyampaian informasi dianggap sebagai kegiatan membagikan ilmu dan sering juga disebut dengan istilah menanamkan, sehingga pengajaran berarti sharing atau tukar pengalaman.

Hukum pidana adalah hukum yang mengenai petunjuk yang dimana didalamnya ada kewajiban yang harus ditaati, dan jika melakukan kesalahan akan dikenakan sanksi sesuai dengan perintah yang sudah ditetapkan. Kekerasan didalam dunia pendidikan tidak hanya terjadi kepada siswa namun pada saat ini banyak sekali kita temui guru yang menjadi korban dari tindak pidana yang dilakukan siswa itu sendiri. Dalam hal pengajaran dan pembelajaran perlindungan terhadap guru seharusnya lebih di tingkatkan sebab kekerasan terhadap guru semakin meningkat. Ada tindak pidana penganiayaan terhadap guru sudah jelas mencoreng sistem pendidikan Tindak pidana adalah tindakan yang tidak hanya dirumuskan oleh Kitab Undang-Undang Hukum Pidana (Sianturi, 2002). Oleh karena itu siswa yang melakukan tindak pidana penganiayaan terhadap guru saat proses pengajaran dan pembelajaran apalagi sampai menyebabkan kematian terhadap korbannya. Siswa yang dikatakan termasuk anak dibawah umur bisa dikenakan sanksi pidana Mengenai pasal yang dikenakan pada pelaku tindak pidana penganiayaan terhadap guru hingga menyebabkan meninggal dunia pada dasarnya di kategorikan perbuatan yang termasuk penganiayaan. Sanksi pidana kepada pelaku penganiayaan tertuang dalam Pasal 351 s/d 358 Kitab Undang-Undang Hukum Pidana. Jika meninggalnya target merupakan niatan dari orang yang melakukan tindak pidana yang bersangkutan, untuk itu merujuk pada Pasal 338 Kitab Undang- Undang Hukum Pidana dimana menyebutkan: Barang siapa dengan sengaja menghilangkan nyawa orang lain karena bersalah telah melakukan pembunuhan dipidana dengan pidana penjara selambat-lambatnya lima belas tahun.

Tindak pidana penganiayaan terhadap guru dapat dikenakan sanksi pidana sesuai dengan Pasal 338 Kitab Undang-Undang Hukum Pidana. Bila dilihat dari segi usia pelaku dikatakan bahwa pelaku disebut anak. Jika kita merujuk pada Undang-Undang Nomor 35 Tahun 2014 tentang perlindungan anak bahwa anak yang melakukan tindak pidana akan tetap dilindungi oleh Negara dan hukuman pidana penjara bagi anak yang melakukan tindak pidana yaitu setengah dari maksimum ancaman pidana penjara bagi yang sudah dewasa dimana ini tertuang dalam Pasal 18 ayat (2) Undang-Undang Nomor 11 Tahun 2012 mengenai Sistem Peradilan Pidana Anak.

Sanksi awal mulanya terdiri dari satu jenis sanksi yaitu sanksi kriminal mengenai hukuman dalam arti sempit yaitu ada kegiatan hukum oleh lembaga peradilan, kepemilikan sanksi pidana tujuannya yaitu Retributive atau mengenai pandangan lebih maju adalah yaitu pencegahan (Deterrence Prevention) (Safaat, 2014). Patut disadari bahwa norma di dalam Undang-Undang No.14 Tahun 2005 dan Undang-Undang No.20 Tahun 2003 tentang Sistem Pendidikan Nasional sepanjang berkaitan dengan kewajiban memberikan perlindungan hukum kepada guru sangat lemah atau tidak ada daya paksa penegakannya. Dibuktikan kedua Undang-Undang tersebut tidak mengatur sanksi pidana bagi pelaku penganiayaan terhadap guru sehingga tindak pidana penganiayaan tidak dianggap sebagai tindak pidana khusus dengan penanganan yang khusus.Sepanjang ini pelaku penganiayaan masih dijerat dengan pidana umum yaitu Kitab Undang-Undang Hukum Pidana. Sanksi pidana terhadap tindak penganiayaan terhadap guru belum secara khusus menciptakan sistem perlindungan guru yang komprehensif dan juga tegas memberikan mandat kepada lembaga Negara terkait untuk melalukan koordinasi kebijakan dan pengawasan terhadap guru. 


\section{SIMPULAN DAN SARAN}

\section{Simpulan}

Berdasarkan hasil analisis data dapat disimpulkan bahwa penganiayaan terhadap guru diatur dalam Undang-Undang No.14 Tahun 2015 mengenai Guru dan Dosen dan diperkuat dengan terbitnya Peraturan Pemerintah Nomor 74 Tahun 2008. Ada tujuan pengaturan terhadap siswa yang melakukan tindak pidana penganiayaan terhadap guru untuk memberikan efek jera bagi siswa pelaku tindak pidana penganiayaan. Tujuan pengaturan tersebut untuk melindungi siswa yang menjadi salah satu bagian dari pembangunan nasional dan menunjang kemajuan Negara, dan membangun disiplin terhadap siswa serta mengubah tingkah laku siswa tersebut agar menjadi sesuai dengan yang diharapkan serta tidak ada siswa lain lagi yang melakukan perbuatan tersebut, yang kedua sanksi pidana terhadap pelaku merujuk pada Pasal 338 Kitab Undang-Undang Hukum Pidana tentang pembunuhan mengingat pelaku masih dibawah umur maka hukuman yang diberikan kepada pelaku paling lama $1 / 2$ (satu perdua) dari maksimum hukuman pidana penjara bagi orang dewasa sebagaimana telah diatur dalam Undang-Undang Nomor 11 Tahun 2012 mengenai Sistem Peradilan Anak.

\section{Saran}

Adapun yang menjadi saran peneliti yaitu Mengingat Guru adalah pahlawan tanpa tanda jasa yang sepatutnya kita hormati namun dalam menjalankan tugasnya hendaknya perlu ada perlindungan terhadap guru dalam mendidik siswa, justru guru menjadi objek kekerasan peserta didik bahkan orang tua peserta didik, yang kedua kepada aparat penegak hukum dan dinas terkait supaya memberikan sanksi pidana kepada pelaku tindak pidana penganiayaan kepada guru perlu ada peraturan hukum yang mengatur secara tegas tentang sanksi pidana bagi pelaku tindak pidana penganiayaan terhadap guru dengan tujuan untuk meningkatkan efek jera terhadap para pelaku tindak penganiayaan tersebut.

\section{DAFTAR PUSTAKA}

Kunandar. (2011). Guru Profesional. Rajawali Press.

Muhaimin. (2009). Manajemen Pendidikan dan Aplikasinya dalam Penyusunan Pengembangan Sekolah. Prenada Media Group.

Neolaka, G. A. A. (2017). Landasan Pendidikan Depok. Kencana.

Safaat, A. (2014). Teori Hans Kelsen tentang Hukum Konstitusi. Pers Jakarta.

Sianturi, S. R. (2002). Asas-Asas Hukum Pidana di Indonesia dan Penerapan. Storia Grafika.

Sudibyo, A., \& Kiyamudin, E. (2019a). Perlindungan Hukum Terhadap Guru dalam Melaksanakan Tugas Keprofesionalannya Dikaitkan dengan Punishment dalam Mendisiplinkan. Paradigma, 1(2), 1-12.

Sudibyo, A., \& Kiyamudin, E. (2019b). Perlindungan Hukum Terhadap Guru dalam Melaksanakan Tugas Keprofesionalannya Dikaitkan dengan Punishment dalam Mendisiplinkan. Premsuption Of Law, 1(2), 47-69. Taufik, M. (2013). Hukum Perlindungan Anak dan Penghapusan Kekerasan. Rineka Cipta.

Waluyo, B. (2002). Penelitian Hukum Praktek. Sinar Grafika.

Undang-Undang Dasar Negara Republik Indonesia Tahun 1945. Kitab Undang-Undang Hukum Pidana.

Undang-Undang Nomor 14 Tahun 2005 tentang Guru dan Dosen. Undang-Undang Nomor 11

Tahun 2012 tentang Sistem Peradilan Anak. Undang-Undang Nomor 35 Tahun 2014 tentang

Perlindungan Anak. 